\title{
Yabancı Dil Öğretiminde Sorular, Öğrenci Cevapları ve Öğretmen Davranışları
}

\begin{abstract}
Mustafa ŞEVIK*
ÖZ: Sorular Aristo'nun zamanından beri eğitim araştırmalarına konu olmuştur. Eğitimcilerin birçoğu, soruların her türden eğitimin temelini oluşturduğu görüşüne katılmaktadır. Sorular üzerine yapılan araştırmalar zaman zaman soruların sinıflandırılması ile ilgilidir. Bu nedenle bu çalışmada soruların sınıflandırılmasına değinilecek ve farklı tipteki soruların öğrenci cevaplarını nasıl etkilediği tartışılacaktır. Bunun yanı sıra, eğitim süreci içerisinde soruların merkezi yeri tartışlacak ve öğretmen davranışlarına değinilecektir. Ancak, soruların sınıflandırılması eğer farklı soru tipleri farklı dünyalara aitmiş gibi ele alınırsa yanlış anlaşılabilir. Oysa ki farklı tipteki sorular birbirlerine güçlü bir bağla bağlıdırlar ve birbirlerini tamamlarlar. $\mathrm{Bu}$ nedenle bu çalışma farklı soru tiplerinin birbirlerinin yedeği olarak değil, bir bütünün parçaları olduklarını göstermeyi hedef almaktadır. Çalışmada farklı soru tiplerinin farklı hedeflere hizmet ettikleri ve hiç bir soru tipinin bir diğerinden üstün olmadığg iddia edilmektedir. Son olarak ise, soru tipleri ile öğretmenlerin soru sorma davranışları arasında olası bir ilişki olduğu tartışılacaktır.
\end{abstract}

Anahtar Sözcükler: Sorular, soruların sinıflandırılması, öğrenci cevapları, öğretmen davranışları

\footnotetext{
*Yard.Doç. Dr. S.D.Ü. Burdur Eğitim Fakültesi Öğretim Üyesi.
} 


\section{ÖZET}

Araştırmacılar sınıf içerisinde öğretmenlerin ve öğrencilerin ürettiği soruların miktarı, doğası ve yapısı üzerine sayısız araştırma yapmışlardır. Aslında, çoğu öğretmen gerçekte, ne kadar çok soru sorduğunun farkında değildir. Soru sorma yöntemi, öğretmenlerin öğrencilerin öğrenmesini ve düşünmesini sağlamaktaki en temel yöntemlerden biridir ve iyi bir öğretmen aynı zamanda iyi bir soru sorucudur. Sorular üzerine araştırma yapılması soruların çoğu öğretim yönteminin en temel öğesi olmasından kaynaklanmaktadır. Sorgulama eğitim sürecinin temelini teşkil eder, ve bu sorgulama ancak soru sorup cevap verilmesi ile tamamlanabilir.

Eğitimin her kadamesinde, öğrenci ile öğretmen arasındaki iletişimin özünü sorular teşkil eder. Öğretimin vazgeçilmez aracı olan sorular öğrencilerin düşünme becerilerinin geliştirilmesinde de çok önemli bir yere sahiptir. Soruların bu merkezi öneminden dolayı, öğretmenler soruların iletişim ve öğrenme üzerindeki etkilerinden haberdar olmalı ve soruları ve soru sorma davranışlarını gelişterecek yeni yollar aramalıdırlar.

Nasıl soru sorduğumuz ve sorular hakkındaki bilgilerimizi genişleterek, daha zengin sınıf içi iletişimler ve etkileşimler sağlamanın farklı yollarına ulaşabiliriz. Öğrenme soruların bir sonucu olarak gerçekleşir, sorular müfredatın hedeflerine ulaşmasına yardımcı olur, ve iyi bir öğretmen iyi bir soru sorucudur. Dahası, yapılan birçok araştırma soruların birçok öğretmenin kullandığı en temel yöntem olduğunu göstermektedir.

Sınıf içi iletişimin doğasından dolayı, sorular ve soru sormak yabancı dil eğitimi açısından çok daha önemlidir. Van Lier' in (1996)'de öne sürdüğü gibi yabancı dil sınıflarının genel doğasını hiçbirşey 'IRF' (Soru-cevapdönüt) döngüsü kadar iyi sembolize edemez. Bu tip bir döngüde öğretmen soru sorarak iletişimi başlatır, bir öğrenci cevap verir, ve öğretmen dönüt verip başka bir soru sorarak yeni bir 'IRF' döngüsünü daha başlatır. Bunun da ötesinde, yabancı dil sınıflarında, dil hem hedef hem de öğrenmenin gerçekleşeceği araç konumundadır. Ve ülkemizde de olduğu gibi, hedef dil ders dışı ortamlarda çok nadir olarak kullanılıyorsa sınıf içerisinde öğrencilere sunulan bilgiler ve iletişim olanakları çok daha fazla önemli hale gelmektedir. Soruların sınıf içi iletişimin merkezinde olduğu görüşünü kabul edecek olursak, önemi bir kat daha artmaktadır. Araştırmaların çoğu öğretmenlerin bir ders saatinde ortalama 43.6 soru sorduklarını göstermektedir. Eğer bu doğruysa bir öğretmen kariyeri boyunca 1.5 ile 2 milyon soru sormaktadır. Bu sayı, yabancı dil öğretmenleri söz konusu olduğunda 3 ile 3.5 milyona kadar yükselebilmektedir. $\mathrm{Bu}$ verilere 
dayanarak, sorular ve soru sorma hakkında edinilecek olan bilgilerin yabanc1 dil öğretimi açısından öğretmenlerin yararına olacağı şüphesizdir.

Öğretmenlerin, soru tipleri ve soruların öğrenci cevaplarına etkileri konularında bilinçlerinin artması ders planı yapılırken önemli bir rol oynamaktadır ve daha etkili bir öğrenmenin gerçekleşmesine katkıda bulunabilir. Bunların dışında, soruların sınıflandırılmasının bazı diğer yararları da bulunmaktadır. Öğretmenlerin öğrencilerde yaratmak istedikleri davranış değişikliklerine yönelmesine yardımcı olurlar. Ayrıca, ve daha geniş bir açıdan yaklaşıldığında sorular ders materyallerinin değerlendirilmesi için kullanılabilirler.

Soruların sınıflandırılması sınıf doğasının anlaşılmasına katkıda bulunur, çünkü farklı soru tipleri farklı cevaplar gerektirir. Örneğin, sınıf içerisinde sorulan sorular incelendiğinde, alt-seviyeli sorular çok fazla ise ve üst-seviyeli soru hemen hemen hiç sorulmamışsa burada bir sorun olabilir. Çünkü öğrencilerin düşünme ve konuşma becerileri sınırlandırılmış olur. Bunu fark eden bir öğretmen bir sonraki ders planını hazırlarken her iki soru tipinide kullanarak daha dengeli bir plan yapabilir. Tam bu noktada, yapılan araştırmaların sonuçlarına göz atılacak olursa genel olarak alt-seviyeli soruların derslerin büyük bir bölümünde üst-seviyeli sorulardan kat kat daha fazla kullanıldığ 1 söylenebilir. Ancak, alt-seviyeli soruların fazlaca kullanılması öğrencilerin hedef dili kullanma ve pratik yapma olanaklarını kısıtlayacaktır. Bu durum da, yabancı dil öğretimi açısından çeşitli sorunların oluşmasına neden olacaktır. Örneğin, öğrencilerin konuşma becerileri eşit oranda gelişmeyecek hatta diğer becerilerinin gelişimine göre bulundukları seviyenin gerisinde kalacaktır. Oysa dil öğretiminde hedef dört temel becerinin (konuşma, dinleme, okuma, ve yazma) aynı anda geliştirilmesi olmalıdır. Diğer tarafta ise, üst-seviyeli soruların öğrencileri düşünmeye yönlendirdiği, daha özgür ve daha uzun cevaplar gerektirdiği bilinmektedir. $\mathrm{Bu}$ nedenlerden dolayı, öğretmenler soru tipleri ve öğrenci cevaplarına etkileri konusunda bilgi sahibi olmalı, sınıf içerisinde sordukları sorular arasında bir denge kurmalıdırlar. Ayrıca uygun soruların uygun zamanda sorulması, daha etkili bir zaman yönetimine yardımcı olarak ders zamanının daha etkili kullanılmasını sağlayacaktır.

Öğretmenlerin soru sorma davranışlarından genel olarak bahsedecek olursak, dikkat edilmesi gereken iki temel teknikten bahsetmek olasıdır. Birincisi "dağıtım"dır (distribution). Bu davranış, soruların kime sorulduğu ile ilgilidir. Sorular doğrudan tek bir öğrenciye sorulabilir, sınıftaki belli bir gruba sorulabilir(örneğin, kızlara veya erkeklere), veya doğrudan tüm sınıfa sorulabilir. Öğrencilerin katılımını sağlamak ve motivasyonlarını arttırmak için ise, durumu sınıf seviyesinin altında olan öğrenciler desteklenmeli, 
cevap vermeye çalışanlar cesaretlendirilmeli, farklı görüşlere ve bakış açılarına hoş görüyle bakılmalı ve zeki öğrencilerin verdikleri cevaplar ve derse katkıları takdir edilmelidir. İkincisi ise "takviye"dir (reinforcement). $\mathrm{Bu}$ davranışın temelinde ise, öğrencilere başarı duygularının aşılanması yatmaktadır. Böylece, bu yaklaşım öğrencilere öz-güven kazandıracak ve hedef dili daha fazla ve daha özgürce kullanmaya başlayacaklardır.

Sonuç olarak, soruların sınıflandırılması ve farklı soru tiplerinin öğrenci cevapları üzerindeki etkilerinin araştırılması boşa geçirilen zaman olarak görülmemelidir. Çünkü öğretmenlerin oldukça geniş bir soru teknikleri repertuarına ihtiyaçları vardır ve dersin veya yapılan uygulamanın amaçları doğrultusunda farklı zamanlarda farklı soru tiplerine ve tekniklerine ihtiyaç duyacaklardır. Örneğin, bir gramer aktivitesi esnasında öğrencilerin konuyu anlayıp anlamadıklarını sormak isteyen bir öğretmen alt-seviyeli bir soruya ihtiyaç duyarken, aynı öğretmen bir konuşma dersinde sınıfta konuşma atmosferi yaratabilmek için üst-seviyeli bir soruya ihtiyaç duyacaktır. Dolayısı ile her iki soru tipi de farklı zamanlarda, farklı hedefler için öğretmenlere gerekmektedir. Ancak, burada özellikle vurgulanması gereken son bir nokta bulunmaktadır; alt-seviyeli ve üst-seviyeli sorular birbirinin yedeği olarak görülmemelidir. Tam tersine aynı takımın oyuncuları gibi algılanmalıdırlar. Biri diğerinden daha üstün değildir, sadece farklı hedefler doğrultusunda kullanılmalıdırlar. Etkili öğrenme ise farklı soru tipleri ayrı ayrı değil, birlikte kullanıldıkları zaman meydana gelir. 


\title{
Questions, Student Responses, and Teacher Behaviours in the Teaching of Modern Foreign Languages
}

\author{
Mustafa ȘEVIK*
}

\begin{abstract}
Questions have been the subject of educational research since the time of Aristotle. Many, I believe, would agree with the assumption that questions are at the core of any educational process. Research on questioning focuses on question classification from time to time. Thus, this study will focus on question types in relation to their possible effects on student responses after briefly setting out the centrality of questions in the teaching process, as well as teachers' questioning behaviours. The classification, however, might create a misunderstanding when different question types are seen as belonging to different worlds rather than being inextricably linked and as complementary of each other. Therefore this study aims to demonstrate that different question types should not be seen as the exception of each other but as parts of a whole. It will be argued that different question types serve different purposes, and that no question type is superior to the other. Finally, it will be argued that there is possibly a relation between the type of the question and the teachers' questioning behaviour.
\end{abstract}

Key Words: Questions, question classification, student responses, teacher behaviours

\footnotetext{
${ }^{*}$ Asist. Prof. Dr. S.D.Ü. Burdur Faculty of Educational.
} 


\section{Introduction}

Questioning is central to any teaching-learning situation, therefore there is a growing and widening interest in the study of questioning which has attracted the attention of scholars since Aristotle. Educational researchers have variously investigated the amount, nature and pattern of questions produced by teachers and students in the classroom. In fact most teachers fail to realise just how many questions they really ask. In quoting Ascher (1961), for example, Gall (1970: 707) called the teacher "a professional question maker" and claimed that the asking of questions is "one of the basic ways by which the teacher stimulates student thinking and learning". The value of focusing on teachers' questions is that they constitute the basic unit underlying most methods of classroom teaching and their continued study deserves the strong support of researchers. Kerry (1998) too points to the centrality of questions in arguing that enquiry lies at the heart of the education process; an enquiry takes place through the formulation of questions, problems and hypotheses, which require answers and solutions.

Perrott (1982) takes this further and, whilst acknowledging the welldocumented critical role played by questions in the educational process, argues that questions may well be the most important activity in which teachers engage. To substantiate her claim, she reviews some of the research about the nature of classroom discourse in which teacher questions occupied the core of the teaching sequence. Questions are the core around which all communication between teacher and pupils take place at every stage in education. They are fundamental tools of teaching and lie at the very heart of developing critical thinking abilities in pupils. Because of their central role, it is important that teachers are familiar with the impact questions have on communication and learning in the classroom, and find ways to improve the use of questions by themselves and their students (Kissock and Iyortsuun 1982).

As a result of extending our knowledge about questions and examining how we question, we will arrive at some answers which will generate richer classroom interactions. Learning occurs as the result of questions; questions serve to focus the objectives of the curriculum; a good teacher is a good questioner (Morgan and Saxton 1991). Furthermore, statistics suggest that questioning is indeed the major teaching tool for many teachers (see Richards and Lockhart 1994).

The importance of questioning in the teaching of foreign languages becomes ever more important due to the nature of classroom interaction. As I shall point out in detail later, research findings show the dominance of 
display questions and this indicates possible ways in which teachers ask questions and react to answers, and consequently how classroom interactions are shaped. Van Lier (1996) argues that there is probably nothing that symbolises classroom discourse quite as much as the "Initiation-ResponseFeedback" (IRF) pattern. In this type of interaction the teacher initiates an exchange, usually in the form of a question; a student answers, and the teacher gives feedback; and the teacher initiates the next cycle by asking another question and so on. The following extract shows how the IRF pattern works:

T: Excuse me, where is the post Office?

S: All the way down this street and then two blocks at right.

T: Good....

In traditional classes (where the focus is on transmission of information), the percentage of utterances that fall neatly into this three-part structure may be over half. Van Lier (op cit.) counted between $50 \%$ to $60 \%$ of the secondary school data as consisting of three part exchanges.

Tsui (1995) argues that in the language classroom, questioning is even more important because language is at once the subject of study as well as the medium for learning. In situations where the target language is seldom used outside the classroom and the students' exposure to the target language is therefore mainly in the classroom (which is usually the case in the countries where English is taught as a foreign language), the kind of input and interaction that is made available to the student is particularly important. Therefore, if "good" questions should cognitively challenge learners and increase their participation in learning, then effective questions becomes ever more important. And as Tsui (op cit.) argues, teacher questions generate a major part of classroom interaction in most English as foreign language classrooms. Two other remarkable examples to conclude the discussion about the centrality of questions in classroom discourse would be the argument that according to calculations, most teachers ask an average of 43.6 questions per teaching hour. If this is true teachers are likely to ask between 1.5 and 2 million questions in an average career. Moreover this number could well rise to 3 and 3.5 million in the case of language teachers (Kerry 1998). On this matter Gebhard (1996) reports that teachers of English as a foreign language ask a lot of questions. Using observations of six teachers -all teaching in different contexts in Japan- he found that teachers used an average of 52 questions every thirty minutes during teacher initiated activities. Based on this evidence, he argues that knowledge about questions 
and questioning behaviours can benefit teachers who want to provide opportunities for meaningful student interaction in English.

\section{The Reasons for Asking Questions}

Teachers ask questions for multiple purposes in the classroom. I believe that understanding these purposes might actually expand the teacher's use of questioning in instruction. Such purposes also have a direct relation as to which type of question would suit best for the situation at hand. A language teacher, for example, whose immediate goal is to test the students' knowledge about the simple past tense using the irregular verb forms would rather ask lower-order display questions; e.g. What is the past form of the verb "go"? However, if the aim would be to enhance the students' use of simple past tense then the teacher would rather ask higher-order referential questions; e.g. What did you do yesterday night? On more general terms there are various reasons as to why teachers ask questions, and I would like to borrow from Ur (1996: 229) who proposes the following criteria:

a. To provide a model for language or thinking

b. To find out something from the learners (facts, ideas, opinions)

c. To check or test understanding, knowledge or skill

d. To get learners to be active in their learning

e. To direct attention to the topic being learned

f. To inform the class via the answers of the stronger learners rather than through the teachers' input

g. To provide weaker learners with an opportunity to participate

h. To stimulate thinking (logical, reflective or imaginative); to probe more deeply into issues

i. To get learners to review and practise previously learnt material

j. To encourage self expression

k. To communicate to learners that the teacher is genuinely interested in what they think

It is also worth reminding at this point that a teacher might ask any one question with more than one of these aims in mind; for example, the teacher might both wish the learners to be active and at the same time direct attention to the topic being learned. 
In most cases the language teachers' motive in asking questions is usually to get students to actively engage orally with the language material. Thus, an effective question elicits fairly prompt, motivated, relevant and full responses. If, on the other hand, the question results in silence, or is answered by only the strongest students, or bore the class, or consistently elicit only very brief or unsuccessful answers, then there is probably something wrong. The following two extracts are examples to when the question and the goal fits and does not fit (Sevik 2001: 209):

T: What are your hobbies? What do you do in your spare time? For example, I can play the guitar.

\section{S1: I read books}

\section{S2: I play football}

T: play football, good, someone else?

The question above was asked in the beginning of a reading lesson about hobbies. The teacher both wanted to motivate the students and wanted them to be active. As the students answered enthusiastically, it can be said that the question reached its aim. First of all the question was very clear and the teacher explained what he meant by the question by giving an example herself.

The same, however, can not be said for the following extract (Sevik op cit.: 214):

T: ....example, Can you tell me an example of this category?

Sts: ...long silence

T: For how long have you been studying English at this school? Four? Five?

Sts: (shout out answers) five, six...

T: five, six... Exact year?

S1: six years

T: six, let's say six...

The teacher was engaged in a grammar activity and wanted to check the students' previous knowledge about the "present perfect tense". However, the initial question was not very appropriate since there was a long silence in the class. This question was open-ended. Later the teacher asked another question, this time a closed one, and the students started to shout out 
answers. Even though the first question was clear, it was too abstract for the level of the students therefore there was no answer in the first place and the teacher had to rephrase her question. As it can easily be seen in these two examples there is a connection among question types, the goal in asking a question and student response. Therefore, I strongly believe that knowledge about the classification of questions leads to a better understanding of classroom discourse and understanding classroom discourse better would probably lead to better teaching by the teacher and better learning by the students. Besides, it would help greatly in the management of classroom time. Consequently, this would lead to saving time by using the appropriate question techniques at the appropriate time.

\section{The Classification of Questions And Effects on Student Response}

I would briefly like to review the literature on question types in order to explore the tenet that raising teacher awareness of question types and their possible effects on student responses might play an important part in lesson planning and ultimately assist in encouraging learner autonomy. In addition, the application of classification of questions might serve a number of useful purposes. They direct the teacher's attention to the behaviour changes $s /$ he wants to see in students as a result of instruction. They might serve as a framework with which questions can be prepared. And on a wider dimension, their use might help in evaluating instructional materials, like textbooks (Kissock and Iyortsuun, 1982). So greater awareness of questions and their effects might help teachers in their selection.

The most commonly used term for differentiating questions is probably the classification of display and referential questions. Display questions are those where the teacher already knows the answer but requires the student to display knowledge. In this respect they could be classified as lower-order questions (see Bloom, 1956 for the classification of lower-order and higherorder questions). Long and Soto (1983) refer to display questions as "knowledge checking" and argue that they generate interactions that are typical of didactic discourse. This stance relates to the nature of classroom interaction in that the IRF pattern is the mostly seen type of classroom interaction. Display questions offer a way to practice language or drill students and most students both need and like them as they create a competitive and fun atmosphere in the classroom. In the next extract for example (Sevik 2001: 205), the teacher was engaged in a grammar activity about the use of "single sylable comparative adjectives". When the teacher asked a display question most of the students were shouting out answers and racing with each other, even though the classroom was a bit noisy, the enthusiasm of the students was worth seeing: 
T: ... who can give me an example?

S1: tall/taller

S2: big/bigger

S3: short/shorter...

T: OK, OK more silent please...

Referential questions on the other hand, request information not known by the questioner and therefore have greater potential to generate social discourse. They are a means through which to bring real questions into the classroom, and they are aimed at communication rather than testing the students' knowledge. Therefore when the aim of the teacher is to enhance students' speaking skills and to create a social-like atmosphere in the classroom, the teacher would rather ask referential questions to which the students' answers are more meaningful and longer in most circumstances. However, it is worth mentioning at this point that both type of questions have a place in the classroom discourse, and the determinant of the question type should be the aim of the particular activity and the level of the students (see Brock 1986, Gebhard 1996, and Tsui 1995). It is therefore important to realise that these two question types are not exclusive of each other but that they are two components of the same whole.

The classification of questions contributes to understanding the nature of classroom discourse, in that different questions require different student responses. On this matter, research findings show the the dominance of display question type over referential question type. At this point Gall (1970) states that educators generally agree that teachers should emphasise the development of students' skills in crititcal thinking rather than in learning and recalling facts. However, Gall also reflects on mainly American and British research spanning more than half a century which indicates that teachers' questions emphasise factual knowledge. Therefore it would be appropriate to conclude from Gall's findings that in half a century there had been little change in the types of questions teachers ask in the classroom. According to the research, therefore it would appear that about $60 \%$ of teachers' questions require students to recall facts; about $20 \%$ require students to think; and the remaining $20 \%$ are procedural.

Whilst there have been some significant changes in pedagogy, it would seem that there have been relatively few changes in relation to the frequency of lower-order questions. Kerry's (1998) argument that all major research agrees upon the dominance of lower-order questions over time, supports this view. Kerry (op cit.) suggests that the percentage may vary from about $60 \%$ 
upwards. In his research into secondary schools in Britian, only $3.6 \%$ of all teacher questions fell into one of Bloom's (1956) higher-order categories. Richards and Lockhart (1994) who classify questions as "convergent" and "divergent", again demonstrated the dominance of lower-order convergent questions. They argue that these questions serve to facilitate the recall of information. They do little to generate student ideas and classroom communication. Overuse of these questions types will limit student opportunities to produce and practice the target language, which can be counted as a serious handicap in the teaching of modern foreign languages. Such research findings repeatedly demonstrate the dominance of lower-order questions as well as the probability that their overuse limits social communication. Therefore, I would like to argue for more of a balance between lower- and higher-order questions, thereby suggesting an increase in the use of higher-order questions.

In considering the possible effects of questions on student responses, it is clear that Richard's and Lockhart's (op cit.) findings apply to other research as well. Brock (1986), for example tried to determine if using higher frequencies of referential questions had an effect on adult English as a second language classroom discourse. He found that learners' responses to referential questions were on average more than twice as long and more than twice as complex in terms of syntax as responses to display questions. As this study suggests, if the use of referential questions increases the amount of learner output and participation, then such questions are important classroom tools to generate more target language use by the learners. Tsui (1995) who writes in a similar way argues that the kinds of questions asked have important effects on student responses and the kinds of interaction generated. Display questions are likely to encourage to regurgitate facts or preformulated language items. They also discourage students from trying to communicate their own ideas in the target language and therefore potentially restrict students' language output. Asking referential questions on the other hand might well reinforce critical thinking and as a consequence of increased articulation, language output might also increase.

In my study (Sevik 2001: 191-2) the dominance of lower-order display questions over higher-order referential questions was also observed in English as a foreign language classrooms in Turkey. Lower-order questions were observed almost four times more than higher-order questions. Therefore, I believe that it would be appropriate at this point to look at some examples from my research as to why teachers chose to ask display questions at certain times and referential questions at other times; 
T: ...yes, the fourth one?

S1: ' $f$ '. They started to grill some sausages

$\mathbf{T}$ : and another one, yes, please?

S2: 'e'. They go into the sitting room to watch T.V.

T: and the following, yes?

S3: 'b'. Jamie wants some water and smells something burning

T: good, and the next one?....

T: ...What is her name?

S: Nicola, her name is Nicola

$\mathbf{T}$ : yea, her name is Nicola...

The teachers later explained in the feedback conference that they were engaged in a "correct order activity" and a "text comprehension", and because the students answered correctly, it was going well, and added that the students were enjoying themselves. I would like to point out that both of the exercises were aimed at checking understanding (reading comprehension) and as such took the form of 'mechanical' interactions. I found out that lower-order questions were mostly asked during textbook exercises such as; i.e. "fill in the blanks" and/or vocabulary exercises. These findings might suggest that textbook exercises, reading comprehension activities, and grammar activities tend to encourage, in most cases, a more mechanical interaction shape (lower-order questions) in English as a foreign language classrooms. However, it is also worth mentioning at this point that, the teachers' comments that the students were enjoying themselves, I would argue, illustrates that this type of questioning (lower-order) pattern may have a motivational value in the teaching-learning process. This also relates to the argument that teachers should operate a variety of questioning patterns, and that every questioning pattern has a place and importance in teaching.

Below are two other example extracts from the same study (Sevik 2001: 210-3), when the teachers asked higher-order questions:

T: have you got a sister?

S: yes, I have

T: himm, imagine...her teacher asked her to draw a parrot, but she does not know a parrot. How do you describe it? 
S: err, an animal with colourful feather, an animal which can fly, an animal which lives in a 'kafes' (cage)

T: yes, anything else?

S: the animal which can talk

T: ok, thank you...

T: ... so you have a computer?

S: yes

T: for how long have you had your computer?

S: three years

T: ... and what was the reason you would like to buy it?

S: I wanted a computer from my parents for internet and games

T: So you are more interested in internet and games. What do you do with the internet?

S: I am chatting with my friends and err searching for my studies

T: very good. I would like to shake your hand for this...

At a first glance to the two examples above, one can easily see that there is some sort of almost-real communication going on in the classroom. As compared to the answers given to the previous display questions, the answers here is much longer and much more meaningful. Therefore, it is possible to argue that when teachers ask open-ended questions students have more opportunity to speak and express themselves freely. As the teachers later explained in the feedback conferences they asked these questions with the basic aim of establishing "real communication". It is also worth mentioning that the use of higher-order questions doubled between the first and third weeks of my study. Thus, indicating that simply paying attention to question types and being aware of their possible effects on student responses might help teachers in creating a more social-like atmosphere in foreign language classrooms.

\section{Questioning Behaviours and Question Types}

French (1963) argues that oral questioning, particularly in the first years of the course, is primarily a form of drill, not a test of knowledge, which in a way confirms the earlier argument that lower-order questions dominate classroom discourse. In relation to teachers' questioning behaviour Kerry (1998) argues that there is certainly evidence to suggest that teachers use the 
same repertoire of questioning skills, and the same patterns of questions lesson after lesson. The number and type of questions used by an individual teacher tends to remain constant from one observed occasion to the other. If this is the case, the foundations for teacher questioning techniques are crucial. A deepening awareness could help educators to explore if there are more effective strategies that can be used widely, and would help teachers in analysing their own teaching. It could well be helpful in extending existing patterns and guide the way to exploring better and more efficient techniques.

The discussions so far about the classification of questions and the dominance of lower-order questions, I believe, has already indicated possible ways in which teachers ask questions and react to answers. As I mentioned earlier, the 'IRF' sequence coined by Van Lier (1996) symbolises classroom discouse in the most general terms and that the percentage of utterances that fall neatly into this three-part structure may be over half. Van Lier (op cit.: 150) describes the features of the 'IRF' sequence as follows:

a. It is three turns long

b. The first and the third turn are produced by the teacher, the second by the student

c. The exchange is started and ended by the teacher

d. The first teacher's turn is designed to elicit some kind of verbal response from a student. The teacher often already knows the answer, or at least has a specific idea in mind of what will count as a proper answer

e. The second teacher's turn (the third in the exchange) is some kind of comment on the second turn. Here the student finds out if the answer corresponds with whatever the teacher has in mind

f. It is often clear from the third turn whether or not the teacher was interested in the information contained in the response, or merely in the form of the answer, or in seeing if the student knew the answer or not

g. If the exchange is part of a series, as is often the case, there is behind the series a plan and a direction determined by the teacher. The teacher leads, the students follow

The IRF exchange can be initiated in two different ways; either general, unspecific elicitation where the teacher addresses the question to all the students or specific, personal elicitation where the teacher selects one student to provide the answer. The teacher can also use the IRF exchange to make 
the students repeat something verbatim, to require them to produce previously learned material from memory, to ask the students to think and then verbalise those thoughts, and to ask the students to express themselves more clearly or precisely.

In relation to teachers' behaviour in asking questions Morgan and Saxton (1991) discuss two techniques. The first one is "distribution", which refers to the way in which questions are directed. Questions can be directed to an individual, to a particular group in the classroom (such as girls or boys), or to the whole class. The key for unlocking general participation is to support the weak, encourage the triers, to tolerate contrary opinions and appreciate the contributions made by bright students. The second technique is "reinforcement". The effect of this technique is to give students a feeling of success, a feeling that they are on the right track which in turn gives them the sense that they have some control. Reinforcements that the teachers mostly use may be in the form of: verbal reinforcement; words like 'good, well done, that is interesting, good point', and using the students' words or ideas, minimal encouragements, audible prompts such as 'ummm, uh, so...?, yes...?' and non-verbal reinforcements; such as eye contact, facial expression, body gestures and positions (also see Doff 1995).

In my research (Sevik 2001), I also came up with similar results that most of the question-answer interactions observed, fell into Van Lier's (op cit.) IRF sequence. The teachers in my study operated at three levels when they heard a true or expected response. These are: mechanical level (dominated by lower-order questions); oral and visual, progressive level (dominated mostly by lower-order and some higher-order questions), and advanced level (dominated by higher-order questions). I have identified thirteen teacher behaviour classifications and the mostly observed five behaviours are as follows: The teacher;

a. Repeats student response and moves on

b. Praises the student and moves on

c. Asks the student to write his/her response on the board

d. Makes an explanation or interpretation after response

e. Asks further questions to the student about his/her response

The first three teacher behaviours mentioned above are examples of when the question was in the form of lower-order, and in most cases the class was either occuppied with activities from the textbook or with grammar practice. Therefore the teachers mainly operated at the mechanical level. The 
fourth teacher behaviour was observed when the class was practising new grammar points and from time to time when the question was open-ended. As this type of behaviour is different in form from the IRF sequence, I called it the progressive level where the teacher is moving towards real communication. And finally the fifth teacher behaviour was observed when the teacher asked higher-order questions with the purpose of establishing real communication, hence I called it the advanced level.

\section{Conclusion}

The classification of questions is a valuable enterprise when we realise that teachers should have a large repertoire of questioning skills and that they should make use of different question types at different times according to the goal of the activity at hand. Otherwise, if we try to search for a panacea question type to suit all situations, our efforts will be in vain. Thus for example, a display question asked during a grammar activity for the purpose of checking understanding is at least as valuable as a referential question asked during a communication activity for the purpose of creating a communicative atmosphere in language classrooms. I would like to also suggest that even a display question asked for checking understanding has at least some sort of communicative value, since the same question may also be asked in real-life daily communications. The following example where the teacher checks whether or not the students understood the modal verb "can" looks like a display question at a first glance. However, the same question may well be asked during a job interview in a real-life daily situation;

T: Can you speak English?

S: Yes, I can

T: Can you use a computer?

S: No, I can't

I believe that lower-order display questions feed-forward towards higher-order referential questions. Thus, students would only be able to answer an open-ended question after s/he has reached a certain level in the target language. So a student would be able to answer the question; "How do you usually spend your weekends?" only after s/he has practiced to answer display questions like; "Do you go to the cinema at the weekends?, Do you meet your friends at the weekends?, and etc.". I therefore, argue that lowerand higher-order questions should not be seen as being the substitute for one another. They should rather be seen as teammates. And learning can only occur effectively when they are used in harmony. 
My readings into questions and questioning showed no specific reference to a link between question types and teachers' questioning patterns. However, depending on my experience and my observations I would like to suggest that there is possibly a significant link between question types and teachers' questioning patterns. Thus, I shall borrow from my research (Sevik 2001: 251) to show the link in Figure 1 below.

Figure 1: The relation between question types and teachers' questioning behaviours

\begin{tabular}{|ll|l|}
\hline Question Type & Questioning Behaviour \\
\hline Lower-order & $\longrightarrow$ & $\begin{array}{l}\text { Mostly mechanical level and progressive } \\
\text { level }\end{array}$ \\
\hline Higher-order & $\longrightarrow$ & Progressive level and mostly Advanced level \\
\hline
\end{tabular}

As is clear from Figure 1 above, when questions were in the lowerorder category the teachers' questioning pattern mostly operated at mechanical and progressive levels. Thus indicating that the students' free use of target language was restricted and the emphasis was more on checking understanding rather than communication. However, when the questions were in the higher-order category the teachers' questioning mostly operated at advanced level, which indicates that students were provided with more opportunities to speak freely and the emphasis was on communication. I would therefore argue that simply by looking at teachers' questions it is possible to guess what kind of atmosphere is created in the classroom. Once the teachers are aware of the effects of questions on student responses, they have the chance to choose between lower- and higher-order questions according to the aim of the particular activity. And my study showed that paying attention to question types may actually increase the use of higherorder questions. Thus for example, the teachers' questions that fall into higher-order category almost doubled between the first and third weeks of the study. And this in turn gave the students more freedom of speech in the target language and increased the quality of student response both in terms of quality and quantity.

\section{REFERENCES}

Ascher, M.J. (1961). Asking questions to trigger thinking. NEA Journal, 50, 44-6.

Bloom, B.S. (1956). Taxanomy of educational objectives: Handbook 1: Cognitive domain. New York: David McKay. 
Brock, C.A. (1986) The effects of referential questions on ESL classroom discourse. TESOL Quarterly, 20(1),47-59.

Doff, A. (1995). Teach English: a training course for teachers -trainers handbook. Cambridge: Cambridge University Press.

French, F.G. (1963). Teaching English as an international language. Oxford: Oxford University Press.

Gall, M.D. (1970). The use of questions in teaching. Review of Educational Research, 40 (5), 707-21.

Gebhard, J.G. (1996). Teaching English as a foreign or second language: a teacher self-development and methodology guide. Michigan: The University of Michigan Press.

Kerry, T. (1998). Questioning and explaining in classrooms. London: Hodder and Stoughton.

Kissock, C. \& P. Iyortsuun. (1982). A guide to questioning: classroom procedures for teachers. London: The Macmillan Press Ltd.

Long, M.H. \& C.J. Sato. (1983). Classroom foreigner talk discourse: forms and functions of teachers questions. In H.W. Seliger \& M.H. Long (Eds.) Classroom oriented research in second language acquisition. Rowley, M.A.: Newburry House.

Morgan, N. \& J. Saxton. (1991). Teaching, questioning and learning. London: Routledge.

Perrott, E. (1982). Effective teaching: a practical guide to improving your teaching. London: Longman.

Richards, J.C. \& C. Lockhart. 1994. Reflective teaching in second language classrooms. Cambridge: Cambridge University Press.

Şevik, M. (2001). "Modern foreign language student teacher beliefs and practices in relation to questioning and error correction: a clinical supervision approach". Yayımlanmamış doktora tezi, School of Education, University of Nottingham.

Tsui, A.B.M. (1995). Introducing classroom interaction. London: Penguin Books Ltd.

Ur, P. (1996). A course in language teaching: practice and theory. Cambridge: Cambridge University Press.

Van Lier, L. (1996). Interaction in the language curriculum: awareness, autonomy, and authenticity. Addison Wesley Publishing Company. 